\title{
Diabetes \& Ramadan (DaR) Workshop in Turkey
}

\author{
Binnur Okan Bakir ${ }^{1 *}$, Mehmet Akif Buyukbese ${ }^{2}$, Halil Kutlu Erol ${ }^{3}$, Hayrettin Mutlu ${ }^{4}$ and Taner Bayraktaroglu ${ }^{3}$ \\ ${ }^{1}$ Dietician, Nutritian Department, Yeditepe University, Istanbul, Turkey \\ ${ }^{2}$ Medical Director at World Diabetes Center, Dunyagoz Hospitals Group, Istanbul, Turkey \\ ${ }^{3}$ Center for Diabetes \& Obesity, Fatih University Hospital, Istanbul, Turkey \\ ${ }^{4}$ Department of Endocrinology, Bulent Ecevit University, Zonguldak, Turkey \\ *Corresponding author: Binnur Okan Bakir, Dietician, Nutritian Department, Yeditepe University, Istanbul, Turkey, Tel: +90-532-5456670; E-mail: \\ akif_buyukbese@yahoo.com
}

Received Date: Jun 30, 2014, Accepted Date: Jul 07, 2014, Published Date: Jul 10, 2014

Copyright: @2014 Bakir BO. This is an open-access article distributed under the terms of the Creative Commons Attribution License, which permits unrestricted use, distribution, and reproduction in any medium, provided the original author and source are credited.

\section{Editorial}

DAR-Turkey meeting was held in Istanbul on May 16, 2014 with the contribution of 9 universities, 3 state hospitals, 4 family health centres where academics such as internists, endocrinologists, nephrologists, general practitioners, diabetes nurses, nurses from public health of governmental organizations, dieticians from universities and private practice centre. Not only the principles of how to cope with diabetes during month of Ramadan but a workshop such as Ramadan-insulin, Ramadan-oral hypoglycaemic agents, Ramadan-diet, Ramadan-DPPIV inhibitors, ramadan-GLP-1 analogues, Ramadan-psychology have all been discussed as a brain storm among the healthcare professionals.

A study conducted in Istanbul, Turkey assessed 26 patients who fasted at Ramadan with type 2 diabetes; patients mentioned that they changed their medication doses and hours, sleeping hours, physical activity levels and their food preferences by themselves without any professional counselling. The result has showed that $84.6 \%$ of the patients reported that they changed their diet routine and $61.5 \%$ eating habits and food preferences [1].

Epidemiology of Diabetes and Ramadan - EPIDIAR study; which has been conducted in 13 Muslim countries on 12,243 individuals showed that $79 \%$ of type 2 and $43 \%$ type 1 diabetic patient fast during Ramadan [2]. Individuals; not only the diabetic patients but also the healthy subjects attend to change their nutritional habits and food preferences as well as their medications, physical activity and sleeping hours.

When fasting, it has been noted that there is decrease in physical activity and a tendency of overeat when the fast is broken. During Ramadan more dishes and refined foods are prepared than the other days and many families prefer to invite guests and eat together which may increase food consumption. It is also a thought that patients with the fear of hypoglycemia avoid exercising which may contribute in weight changes [3].

Evidence based guidelines for food intake during Ramadan do not exist; a moderate energy and lower carbohydrate intake was found to have a statistically significant positive association with the achievement of normoglycemia. Rates of normoglycemia increases and hypoglycemia and hyperglycemia decrease with the compliance with the professional counselling. Reducing the intake of carbohydrates and spreading the amount over three or four meals (predawn meal, post dusk meal, dinner and bedtime) and maintaining energy requirements from other macronutrients ensures normoglycemia during Ramadan [4].
The nutritional advice should be tailored to individual's special needs and medical problems. It should aim to maintain a Stable body mass. In most studies; $50-60 \%$ of individuals who fast maintain their body weight during the month, while $20-25 \%$ gain or lose weight [1]. The common practice ingesting large amounts of food rich in carbohydrates and fats, especially at the sunset meal should be avoided. Foods containing complex carbohydrates as they are slowly digested and absorbed may be advisable at the predawn meal which should be eaten as late as possible [5].

Food consumptions of 450 non-diabetic individuals fasting at Ramadan were assessed by 24 hour recall method at Alexandra, Egypt. The consumptions were recorded 1 week before Ramadan, during Ramadan (last 2 weeks) and 1 week after Ramadan and the results showed that there was a significant increase of weight (weight gain was defined as $2 \mathrm{~kg}$ or more gain) energy intake, fat (\% of total daily energy intake) and protein (\% of total daily energy intake) intake while there was a significant decrease in carbohydrate (\% of total daily energy intake) intake. And age (being at age of 50 and older) and the level of education were significant factors determining the degree of weight gain [6].

An original multi-centered, randomised, double blinded placebo controlled trial conducted on 70 patients with type 2 diabetes screened food consumptions by 24 hour recall and food frequency questioner (FFQ) three times: before Ramadan, at the 15th day of fasting and 1 week after Ramadan. The results showed that the overall calorie consumption during Ramadan varied significantly prior to initiation of fasting, 15 days after initiation of fasting and end of the fasting period. The percentage of energy intake from dietary carbohydrates prior to fasting, during fasting and at the end of fasting remained almost the same with marginal statistically significance. Protein and fat consumption varied considerably during fasting. Analysis of individual components of the diet showed a substantial increase in dietary components during mid-Ramadan fasting [7].

At non-fasting period at Ramadan, excessive compensatory eating may contribute to hyperglycemia and weight gain [7] while 57 female non-diabetic subjects in Jordan, Singapore figured decreased body weight, body mass index and their food consumption which were analysed by 3 days food record method, their mean energy and nutrient intake were not significantly different before and during Ramadan [8].

The Importances of dietary management have been strongly underscored by the diabetes control and complications trial (DCCT) and UK prospective diabetes study (UKPDS) [1-10]. Although during Ramadan the benefits of fasting appear only in patients who maintain 
Citation: Bakir BO et.al. (2014) Diabetes \& Ramadan (DaR) Workshop in Turkey. J Nutr Disorders Ther 4: e116. doi:

Page 2 of 2

their appropriate diets $[9,10]$, most patients with diabetes find it difficult to understand and comply with the nutritional therapy $[9,11]$.

In conclusion, even though not yet approved data currently present to give permission for those who are eager to fast, healthcare professionals are responsible for educating themselves and patients and their relatives. Medications which are not decreasing blood glucose while fasting (but being effective only after alimentation) such as GLP-1 analogues and DPP-4 inhibitors, fear of hypo and dangerous elevations of postprandial glucose levels are not the whole story. Once allowed for fasting does not mean that the next Ramadan will be uneventful.

\section{References}

1. Çelik S, Pinar R, Kubat Üzüm A, Salman S (2013) Effects of Ramadan Fasting on Daily Life and Metabolic Condition in Patients with Type 2 Diabetes Turkiye Klinikleri J Med Science 33: 1266-1273.

2. Salti I1, Bénard E, Detournay B, Bianchi-Biscay M, Le Brigand C, et al. (2004) A population-based study of diabetes and its characteristics during the fasting month of Ramadan in 13 countries: results of the epidemiology of diabetes and Ramadan 1422/2001 (EPIDIAR) study. Diabetes Care 27: 2306-2311.

3. Azizi F, Siahkolah B (1998) Ramadan fasting and diabetes mellitus. Int J Ramadan Fasting Res 28: 17.

4. Hakeem R, Ahmedani MY, Alvi SF, Ulhaque MS, Basit A, et al. (2014) Dietary patterns and glycemic control and compliance to dietary advice among fasting patients with diabetes during Ramadan. Diabetes Care 37: e47-48.

5. Al-Arouj M, Assaad-Khalil S, Buse J, Fahdil I, Fahmy M, et al. (2010) Recommendations for management of diabetes during Ramadan: update 2010. Diabetes Care 33: 1895-1902.

6. Ezzat S, Amin M (2013) Energy Intake, Dietary Pattern and Physical Activity during the Holy Month of Ramadan and Their Impact on Body Weight. International Journal of Food, Nutrition and Health 6: 291-309.

7. Vasan SK, Karol R, Mahendri NV, Arulappan N, Jacob JJ, et al. (2012) A prospective assessment of dietary patterns in Muslim subjects with type 2 diabetes who undertake fasting during Ramadan. Indian J Endocrinol Metab 16: 552-557.

8. Al-Hourani HM, Atoum MF (2007) Body composition, nutrient intake and physical activity patterns in young women during Ramadan. Singapore Med J 48: 906-910.

9. Mohan V Saroja R, Sudha V (2003) Experience with dietary management in diabetes mellitus in South Indians. In: Malini S, Siddhu A, editors. Nutrition goals for Asia-Vision 2020. Proceedings IX Asian Congress of Nutrition, New Delhi: Nutrition Foundation of India p.528-32.

10. Mafauzy M, Mohammed WB, Anum MY, Zulkifli A, Ruhani AH (1990) A study of the fasting diabetic patients during the month of Ramadan. Med J Malaysia 45: 14-17.

11. Katibi IA, Akande AA, Bojuwoye BJ, Okesina AB (2001) Blood sugar control among fasting Muslims with type 2 diabetes mellitus in Ilorin. Niger J Med 10: 132-134. 